\title{
Penyuluhan Perubahan Prilaku Hidup Bersih dan Sehat Masyarakat Dalam Pencegahan Covid 19
}

\author{
Tauhid*1, Muhammad Taufiq ${ }^{2}$, Adi Hidayat Argubi ${ }^{3}$, Surip $^{4}$ \\ 1,2,3,4,Program Ilmu Administrasi Negara, Sekolah Tinggi Ilmu Sosial dan Ilmu Politik Mbojo \\ *e-mail: tauhid@stisipbima.ac.id ${ }^{1}$,m.taufiq@stisipbima.ac.id ${ }^{2}$,adi.hidayat@ stisipbima.ac.id ${ }^{3}$, \\ surip@stisipbima.ac.id ${ }^{4}$
}

\begin{abstract}
The corona virus has an impact on death and continues to increase, thus providing fear, trauma and stress for the community. The Service Team provides counseling and assistance in changing clean and healthy living behavior for the community in the South Rabangodu Village. The method used is counseling and mentoring. Participants include RT, RW, and the community. The results obtained: First; Outreach activities in providing information regarding the 19 results of the corona virus (covid) pandemic have had an impact on increasing knowledge and awareness for the public in implementing the $3 M$ (washing hands, wearing masks and maintaining distance) in daily life. Second; Assistance activities for the community have been able to prepare hand washing facilities in every house, each house has been planted with a living pharmacy, the dawn movement for a clean environment, as well as community mutual assistance activities in creating a healthy village through the environmental clean Friday movement (JUMPA BERLIAN), with changes in clean and healthy living behavior. public health, impact on efforts to prevent covid 19.
\end{abstract}

Keywords: Clean and healthy behavior for the community

\begin{abstract}
Abstrak
Virus corona berdampak terhadap kematian dan mengalami peningkatan terus menerus, sehingga memberikan rasa takut, trauma dan strees bagi masyarakat. Tim Pengabdian memberikan penyuluhan dan pendampingan dalam merubah prilaku hidup bersih dan sehat bagi masyarakat di Kelurahan Rabangodu Selatan. Metode yang digunakan adalah penyuluhan dan pendampingan. Peserta meliputi RT, RW, dan masyarakat. Hasil yang diperoleh : Pertama; Kegiatan penyuluhan dalam pemberian informasi yang berkenaan pendemi virus corona (covid) 19 hasil sudah berdampak pada peningkatan pengetahuan dan kesadaran bagi masyarakat dalam menerapkan 3 M (mencuci tangan, memakai masker dan menjaga jarak) dalam kehidupan sehari-hari. Kedua; Kegiatan pedampingan terhadap masyarakat hasil sudah dapat menyiapkan tempat cuci tangan disetiap rumah, disetiap rumah sudah ditanami apotik hidup, gerakan subuh lingkungan bersih, serta kegiatan gotongroyong masyarakat dalam menciptakan kampung sehat melalui gerakan jumat bersih lingkungan (JUMPA BERLIAN), dengan perubahan prilaku hidup bersih dan sehat masyarakat, berdampak pada upaya pencegahan covid 19.
\end{abstract}

Kata kunci: Perilaku Hidup Bersih dan Sehat Masyarakat

\section{PENDAHULUAN}

Salah satu yang terpenting dalam penangan covid-19adalah dengan caramengubah prilaku dan kesadaran masyarakat melalui pola hidup sehat.Dengan cara cuci tangan, kasih jarak dan menggunakan masker. Ketiga caratersebut dianggap sangat efektif dalam menghindari terjadinya menderitaakibat covid 19. Intinya disetiap rumah tangga harus dibangun prilaku hidup bersih dikalangan anggota keluarga. Lingkungan yang sehat diharapkanadalah lingkungan yang kondusif bagi terwujudnya keadaan sehat, yaitulingkungan yang bebas dari polusi, tersedianya air bersih, sanitasi lingkunganyang memadai, perumahan dan pemukiman bersih dan sehat, pengelolaan kawasanberwawasan lingkungan, serta terwujudnya kehidupan masyarakat yangsaling bahu membahu dalam memelihara nilai-nilai kearifan lokal.Perilaku masyarakat Indonesia Sehat 2020 yang diharapkan adalahyang bersifat proaktif untuk memelihara dan meningkatkan kesehatan,mencegah resiko terjadinya penyakit serta berpartisipasi aktif dalam gerakankesehatan masyarakat. Diharapkan dengan terwujudnya lingkungan dan perilaku hidup sehat sertameningkatnya kemampuan masyarakat tersebut di atas, derajat kesehatanperorangan, keluarga dan masyarakat dapat ditingkatkan secara optimal,dalam menuju tatanan baru (era new normal). Hal ini sebagaimana dikemukakan oleh 
Murni Br Karo (2020) bahwa kunci pencegahan penularan virus ini dapat menerapkanprilaku hidup bersih dan sehat seperti mencuci tangan, komsumsi makanan sehat, olah raga danistirahat yang cukup. Prilaku Hidup Bersih dan Sehata (PHBS) adalah semua prilaku kesehatan yangdilakukan atas kesadaran, sehinga anggota keluarga atau keluarga dapat menolong dirinya di bidangkesehatan dan berperan aktif dalam kegiatan-kegiatan kesehatan di masyrakat.PHBS merupakanlangkah terbaik dalam pencegahan penyebaran virus ini, sehingga perlu ditanamkan kepada semualapisan lapisan masyarakat tentan pengetahuan PHBS. (Sebagaimana dikutip dalam http://proceedings.ideaspublishing. co.id/index.php/hardiknas/article/view/1/1)

Dalam kaitan dengan itu Kota Bima sebagai salah satu daerah yang tidak terlepas daripenyebaran covid-19.Virus Covid 19 sangat meresahkan masyarakat KotaBima.Setelah ditemukan pasien pertama positif Covid-19 di Kota Bima,Nusa Tenggara Barat, diperkirakan tertular sepulang suaminya dari zonamerah virus corona pada tanggal 15 April 2020.Sampai hari ini jumlah kasussuspek yang masih isolasi sebanyak 7 orang, Discarder 278 orang jadi totalsebanyak 285 orang.Kondisi kasus covid-19 ini di Kota Bima, disebabkanoleh kontak perjalanan dan kontak erat dengan pasien dalam lingkungankeluarga.Kota Bima yang tidak sebagian masyarakat yang tersebar di 42 kelurahan yang di 5 kecamatan tidak mengalami atau menderita covid 19, tetapi kekhawatiran terhadap penyakit ini sudah menyebar keseluruh masyarakat yang di Kota Bima, yang jumlah penduduknya sudah mencapai 86613.000.- jiwa, dan untuk penduduk laki-laki dan perempuan sebanyak 89.819.000,- jiwa. Jadi total keseluruhan jumlah penduduk Kota Bima sebanyak 176.432.000,- jiwa. (BPS Kota Bima, 2020). Sementara itu sesuai dengan obyek pengabdian kepada masyarakat yaitu di Kelurahan Rabangodu Selatan Kecamatan Raba, yang memiliki luas wilayah sebesar $1.43 \mathrm{~km}^{2}$, dengan jumlah penduduk sampai tahun 2020 sebesar 4439 jiwa, terdiri dari jumlah penduduk laki-laki sebanyak 2.257 jiwa dan penduduk perempuan sebanyak 2.192 jiwa. Dengan kepadatan penduduk 3104 jiwa.
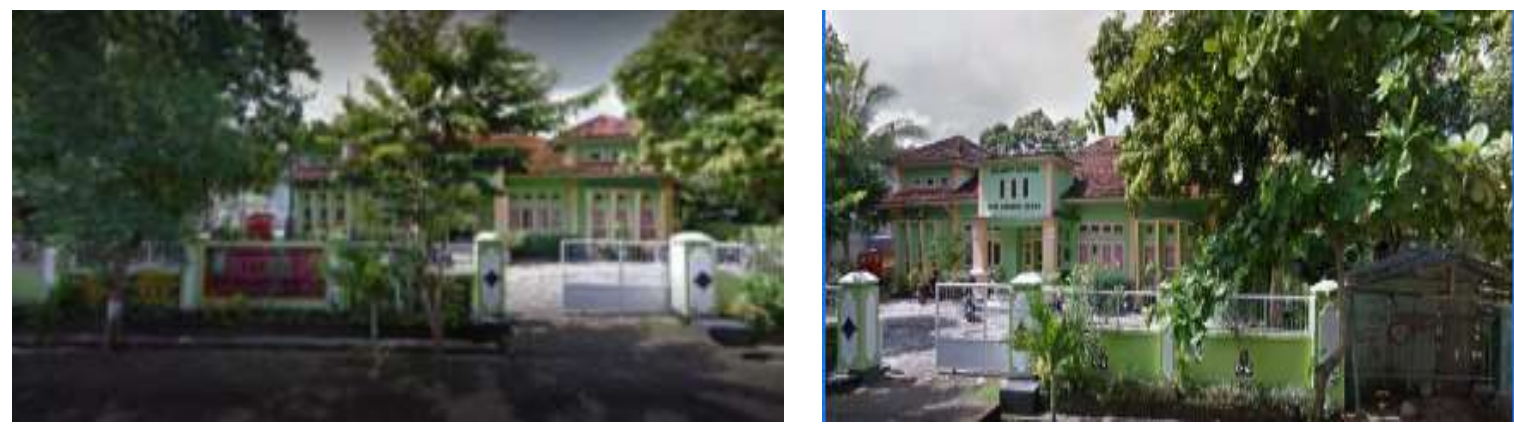

Gambar 1 : Kantor Lurah Rabangodu Selatan Kecamatan Raba Kota Bima

Berkaitan dengan penyebaran virus corona di Kelurahan Rabangodu Selatan sampai dengan 5 April 2021 sudah ada 3 orang yang meninggal akibat pendemi covid 19. Sementaran PDP (Pasien Dalam Perawatan) sebanyak 10 orang, sedangkan OTG (Orang Tanpa Gejala) sebanyak 15 orang. Penyebaran covid 19 di Kelurahan Rabangodu Selatan tidak begitu cepat dan bahkan sekarang Kelurahan Rabangodu Selatan masuk dalam zona hijau. Artinya Kelurahan ini sudah tidak ada kasus atau infeksi virus corona secara meningkat, tetapi sudah berjalan dengan normal. Namun, pada wilayah zona hijau tetap perlu ada kesadaran masyarakat untuk meningkatkan jarak sosial, cuci tangan, hingga pemakaian masker. Disamping itu penyebaran pendemi covid ini tidak tetap kadang berubah-ubah setiap saat, maka perlu mendapatkan perhatian dari warga masyarakat untuk terus berhati-hati dan terus di ingatkan kesadarannya, melalui bagaimana merubah prilaku masyarakat untuk tetap taat dengan prosedur kesehatan (Prokes) dengan tetap menerapkan $3 \mathrm{M}$, yaitu : menjaga jarak, menggunakan masker dan mencuci tangan baik didalam maupun ketika mereka berada diluar rumah dalam merubah prilaku hidup dan bersih masyarakat. Hal ini sejalan sebagaimana dikemukakan oleh Menurut Razi dkk (2020) bahwa perilaku hidupbersih dan sehat (PHBS) untuk pencegahanvirus COVID19 dapat berupa cara mencucitangan yang baik dan benar, cara menerapkanetika batuk, cara 
melakukan Physical Distancing (menjaga jarak fisik), dan cara menjaga kebersihan diri. Sehubungan dengan itu masalah utama yang ada di Kelurahan Rabangodu Selatan masyarakat belum sadar akan pentingnya menerapkan protokol covid 19 dalam rangka untuk mencegah dan mengurangi penyebaran covid 19 yang terus menghantui masyarakat setiap saat. Merujuk pada uraian di atas, maka permasalahannya dapat dirumuskan sebagai berikut : "Bagaimana Penyuluhan dan Pendampingan Perubahan Prilaku Hidup Bersih Dan Sehat Masyarakat Dalam Penanganan dan Pencegahan Penyebaran Covid 19 Di Kelurahan Rabangodu Selatan Kecamatan Raba Kota Bima?.Tujuan kegiatan pengabdian kepada masyarakat adalah untuk memberikan gambaran mengenai kegiatan penyuluhan dan pendampingan perubahan prilaku hidup bersih dan sehat masyarakat dalam penanganan dan pencegahan penyebaran Covid-19 di Kelurahan Rabangodu Selatan Kecamatan Raba Kota Bima.

Berkaitan dengan prilaku hidup bersih dan sehat masyarakat sebagai representatif dalam pencegahan dan penanganan penyebaran covid 19 sudah menjadi suatu tindakan nyata yang dilakukan oleh masyarakat. Menurut Marni Br Karo(2020) bahwa Prilaku Hidup Bersih dan Sehat (PHBS) merupakan strategi yang dapat mencegah penyebaran Covod-19, bahwa masyarakat terus dihimbau untuk meningkatkan prilaku hidup bersih dan sehat dalam upaya pencegahan penyebaran Covid-19, karena perilaku masyarakat sangat berperan penting dalam penurunan angka penyebaran Covid-19. PHBS merupakan salah satu starategi dalam pencegahan penyebaran Covid -19 yang sangat efektif dan mudah dilakukan oleh semua lapisan masyarakat.. Oleh karena pentingnya perilaku hidup bersih dan sehat, perlu dilakukan pemberian informasi secara terus menerus sehingga dapat meningkatkan pengetahuan seluruh lapisan masyarakat untuk menerapkan PHBS dalam kehidupan sehari-hari.Hal senanda juga dikemukakan oleh Razi et al(2020), penerapan PHBS dalam pencegahan virus COVID-19 dapat berupa cara mencuci tangan yang baik dan benar, cara menerapkan etika batuk, cara melakukan physical distancing(menjaga jarak fisik), dan cara menjaga kebersihan diri. Tidak berlebih bahwa Prilaku Hidup Bersih dan Sehat (PHBS)merupakan semua perilaku yang bertujuan memberikan edukasi baik secara individu maupun kelompok untuk meningkatkan pengetahuan dan perilaku sehingga sadar dan mampu mempraktikkan Prilaku Hidup Bersih dan Sehat (PHBS). Melalui Prilaku Hidup Bersih dan Sehat (PHBS) diharapkan masyarakat dapat mengenali dan mengatasi masalah sendiri dan dapat menerapkan cara-cara hidup sehat dengan menjaga, memelihara dan meningkatkan kesehatannya (Notoadmodjo, 2007). Berkaitan dengan itu Pengabdian masyarakat dilakukan di Kelurahan Rabangodu Selatan, sebagai wujud tanggungjawab kampus dalam mengemban tridharma Perguruan Tinggi, apalagi sekarang dihadapkan pada persoalan besar yang dihadapi oleh masyarakat yang sampai hari ini belum ada tanda-tanda penurunan pendemi covid 19, yang menimbulkan trauma yang cukup panjang, rasa stress, panik bahkan bisa menimbulkan kematian yang tinggi. Oleh karena itu melalui kegiatan Pengabdian Masyarakat yang dilakukan oleh Tim Pengabdian STISIP Mbojo Bima, akan bisa memberikan harapan yang besar dalam merubah tatanan pola prilaku, pikiran dan persepsi dalam mengedepankan hidup sehat dengan prinsip sehat diri pribadi, lingkungan sekitar dan masyarakat secara keseluruhan, untuk selalu taat dengan prosedur tetap kesehatan, melalui $3 \mathrm{M}$, yaitu selalu menghindari kerumunan, memakai masker dan mencunci tangan. Dengan kebiasaan yang selalu ditanamkan seperti itu akan tercipta lingkungan yang sehat dan berdampak masyarakat yang sehat pula, sehingga hal ini akan dapat menurunkan kasus pendemi covid $19 \mathrm{di}$ Kelurahan Rabangodu Selatan.

Gambar 2 menjelaskan tentang pada saat masyarakat menghadapi persiapan lomba kampung sehat dalam rangka untuk pencegahan covid 19, melalui upaya membangun kesadaran masyarakat dengan menata dan menciptakan lingkungan yang sehat baik yang menyangkut sanitasi, drainase bersih dan MCK harus ada setiap rumah termasuk air yang bersih. Tim Pengabdian Masyarakat mengambil bagian dengan melakukan pendekatan kepada masyarakat melalui pola pendampingan sosial dengan memberikan pencerahan, keyakinan dan harapan bahwa virus corona dapat dicegah dengan berbagai cara, karena masyarakat sudah terkooptasi dan trauma dengan berita-berita miring diberbagai media cetak, elektronik bahkan media sosial terkait dengan virus corona ini dan dianggap penyakit yang sangat mematikan. 

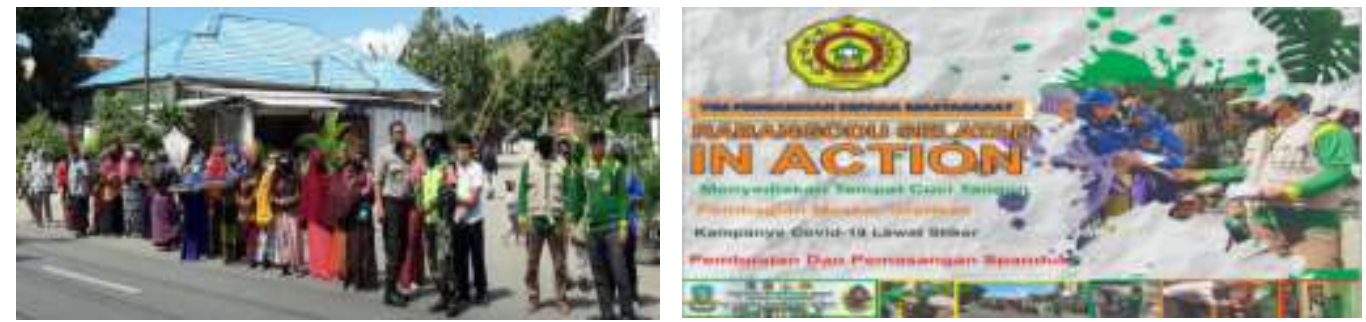

Gambar 2 : Persiapan Masyarakat menghadapi Lomba Kelurahan Sehat bagian dari Pencegahan Penyebaran Covid 19 di Kelurahan Rabangodu Selatan

\section{METODE}

Kegiatan pengabdian masyarakat yang dilakukan Tim Pengabdian Kepada Masyarakat STISIP Mbojo Bima, menggunakan beberapa langkah yang melibatkan metode pelaksanaan terbagi dalam tiga tahap yaitu: (1) tahap perencanaan, (2) tahap pelaksanaan, (3) tahap evaluasi.

1. Tahap perencanaan telah ditetapkan hal-hal sebagai berikut:

a. Melakukan pendekatan kepada pihak yng terkait ketika memulai program dan menawarkan solusi dari permasalahan yang dihadapi mitra. Baik kepada aparat kelurahan, RT, RW, Tokoh masyarakat dan masyarakat.

b. Tim Pengabdian Kepada Masyarakat bersama dengan Lurah, RW, RT dan masyarakat dan pemangku kepentingan membuat persetujuan program dan kesepakatan untuk dukungan kegiatan.

c. Menentukan khalayak sasaran program Pengabdian Kepada Masyarakat yang akan mendapatkan sosialisasi dan pendampingan kegiatan penangan dan pencegahan virus corona atau covid 19.

d. Tim Pengabdian Kepada Masyarakat bersama instansi terkait (Dinas kesehatan Kota Bima) menyiapkan materi-materi dan prosedur yang akan digunakan untuk penyampaian materi sosialisasi penangan dan pencegahan virus corona atau covid 19 kepada masyarakat.

e. Tim Pengabdian Kepada Masyarakat menyusun jadwal kegiatan sosialisasi yang akan diberikan kepada Lurah, RW, RT dan masyarakat.

2. Sedangkan tahap pelaksanaan kegiatannya terdiri atas:

a. Menyiapkan tempat sosialisasi bersama Lurah Rabangodu Selatan.

b. Memberikan sosialisasi/penyuluhan/penyampaian materi tentang penangan dan pencegahan virus corona atau covid 19.

c. Memberikan sosialisasi, praktik, dan simulasi lapangan kepada khalayak kegiatan dalam hal ini Lurah, RW, RT dan masyarakat.

d. Melengkapi peralatan yang menunjang kegiatan sosialisasi berupa LCD atau proyektor.

e. Melakukan pendampingan kepada masyarakat terkait dengan penangan dan pencegahan virus corona atau covid 19.

f. Melakukan kerja sama dengan Dinas Kesehatan Kota Bima dan Satgas Covid 19 dalam koordinasi sejauhmana penangan dan pencegahan virus corona atau covid 19 yang dilakukan oleh Lurah Rabangodu Selatan.

g. Melakukan screening dan pemantauan kepada Lurah Rabangodu Selatan terhadap penangan dan pencegahan virus corona atau covid 19 kepada masyarakat.

3. Tahapan evaluasi terdiri atas:

a. Melakukan evaluasi terhadap kemampuan Lurah Rabangodu Selatan. dalam melakukan penangan dan pencegahan virus corona atau covid 19.

b. Melakukan evaluasi terhadap kemampuan Lurah Rabangodu Selatan dan masyarakat dalam penangan dan pencegahan virus corona atau covid 19. 
c. Melakukan evaluasi terhadap kemampuan Lurah dalam penangan dan pencegahan virus corona atau covid 19 melalui perubahan perilaku hidup bersih dan sehat.

d. Mengevaluasi terhadap kemampuan Lurah dalam penangan dan pencegahan virus corona atau covid 19 dengan baik berdasarkan nilai kejujuran dan transparansi dalam mewujudkan perubahan prilaku hidup bersih dan sehat.

Program Pengabdian kepada masyarakat dalam melakukan sosialisasi dan pendampingan dengan menerapkan beberapa metode yaitu :

1. Ceramah. Metode ini dipilih untuk menyampaikan teori dan konsep-konsep yang sangat prinsip dan penting untuk dimengerti serta dikuasai oleh peserta sosialisasi. Materi yang diberikan meliputi : pengertian virus corona, faktor penyebab virus corona dan upaya pencegahan virus coronan melalui perubahan prilaku hidup bersih dan sehat masyarakat.

2. Display Study (foto dan film). Metode ini dipilih untuk menampilkan kondisi dan aspek terkait kegiatan penangan dan pencegahan covid 19 di daerah lain yang telah lebih dulu maju. Video juga ditampilkan terutama untuk mendukung proses simulasi selanjutnya. Hal ini penting sebagai bahan gambaran riil yang dapat diidentifikasi oleh peserta sosialisasi.

3. Role Play dan simulasi. Pada metode ini peserta secara bergantian akan mempraktikkan cara penangan dan pencegahan virus corona, sebagai representasi dari hasil materi yang telah disampaikan.

4. Pendampingan

Metode ini dipilih pada saat pelaksanaan screening dan sosialisasi penanganan dan pencegahan covid 19, Tim pengabdian Kepada Masyarakat STISIP Mbojo Bima terjun langsung untuk mendampingi Lurah dan masyarakat, sehingga para khalayak betul-betul sudah bisa memahami betul pencegahan covid 19 serta pendampingan dalam mengimplementasikan merubah prilaku hidup bersih dan sehat.

\section{HASIL DAN PEMBAHASAN}

1. Pelaksanaan Program Pengabdian Kepada Masyarakat di Kelurahan Rabangodu Selatan Kecamatan Raba Kota Bima

Berangkat dari profil Kelurahan Rabangodu Selatan Kecamatan Raba Kota Bima yang menjadi sasasaran dari Program Pengabdian kepada Masyarakat Sekolah Tinggi Ilmu Sosial dan Ilmu Politik (STISIP) Mbojo Bima, maka mitra sasaran yang terlibat dalam kegiatan ini adalah Kelurahan Rabangodu Selatan Kecamatan Raba Kota Bima. Permasalahan yang dihadapi oleh masyarakat Kelurahan Rabangodu Selatan adalah ketakutan masyarakat terjangkitnya virus yang mematikan pendemi covid 19 yang sudah mewabah, ada dimana-mana, yang bisa menyerang masyarakat kapan saja, tempat dan waktu yang yang memang sulit diprediksi. Dalam rangka untuk menghindari terjangkitnya virus corona (covid 19) dapat dilakukan melalui merubah kebiasaan jelek atau buruk menjadi prilaku yang bersih dan sehat. Artinya masyarakat dibiasakan untuk tetap konsisten dalam menjaga cuci tangan setiap bila keluar dan masuk kerumah setiap hari. Dan terus mengikuti prosedur tetap (protap) kesehatan.

Oleh sebab itu, cara pencegahan yang terbaik adalah dengan menghindari faktor-faktor yang bisa menyebabkan terinfeksi virus ini, yaitu:

a. Menerapkan physical distancing, yaitu menjaga jarak minimal 1 meter dari orang lain,

b. Menggunakan masker saat beraktivitas di tempat umum atau keramaian, termasuk saat pergi berbelanja bahan makanan dan mengikuti ibadah sholat berjamah di tempat ibadah.

c. Mencuci tangan dengan air dan sabun atau hand sanitizer setelah beraktivitas di luar rumah atau di tempat umum.

d. Tingkatkan daya tahan tubuh dengan pola hidup sehat, seperti mengonsumsi makanan bergizi, berolahraga secara rutin, beristirahat yang cukup, dan mencegah stres. 
e. Hindari kontak dengan penderita COVID-19, orang yang dicurigai positif terinfeksi virus Corona, atau orang yang sedang sakit demam, batuk, atau pilek.

f. Menutup mulut dan hidung dengan menggunakan tisu saat batuk atau bersin, kemudian membuangnya di tempat sampah.

g. Jaga kebersihan benda yang sering disentuh dan kebersihan lingkungan, termasuk kebersihan rumah.

Jadi sederetan-sederatan persoalan-persoalan yang dihadapi oleh masyarakat dalam menghadapi pendemi covid 19, karena sudah meluluhlantahkan dalam berbagai aspek baik ekonomi, sosial, budaya, agama bahkan pertahanan keamanan. Oleh karena itu dalam kegiatan Pengabdian Kepada masyarakat terkait dengan penanganan dan pencegahan covid 19, benarbenar mendapat dukungan semua pihak yang terkait dalam rangka pelaksanaan Program Pengabdian Kepada Masyarakat oleh Tim Pengabdian Kepada Masyarakat Sekolah Tinggi Ilmu Sosial dan Ilmu Politik (STISIP) Mbojo Bima, sehingga kegiatan ini berlangsung dengan lancar, antusias Lurah, RW, RT dan masyarakat mengikuti kegiatan penyuluhan dan pendampingan penanganan dan pencegahan virus corona (Covid 19) di Kelurahan Rabangodu Selatan Kecamatan Raba Kota Bima.

Dengan demikian pelaksanaan penyuluhan dan pendampingan dalam penanganan dan pencegahan penyebaran Covid 19 yang dilakukan oleh pemerintah terutama dalam merubah prilaku hidup bersih dan sehat masyarakat selalu digaungkan oleh pemerintah dalam mewujudkan masyarakat yang betul-betul sehat dan bebas dari covid 19. Jadi peningkatan pengetahuan masyarakat berperilaku hidup bersih dan sehat di Kelurahan Rabangodu Selatan Kecamatan Raba Kota Bima sebagai suatu pengetahuan yang dimiliki oleh masyarakat dengan sadarnya untuk merubah diri supaya berperilaku hidup bersih dan sehat di perkampungan kumuh. Tahapan kegiatan yang dilakukan mencakup : 1 . Pengalaman belajar atau menciptakan suatu kondisi bagi perorangan, keluarga, kelompok dan masyarakat, 2. membuka jalur komunikasi, 3. meningkatkan pengetahuan, sikap dan perilaku dan 4. bina suasana (Social Support), dan 5. pemberdayaan masyarakat (Empowerment) supaya mereka dapat berprilaku hidup bersih dan sehat

\section{Efektivitas Penerapan Metode Dalam Pelaksanaan Program}

Efektivitas penerapan metode yang telah ditawarkan dalam menyelesaikan persoalan mitra program Pengabdian kepada Masyarakat adalah meliputi tahapan :

a. Efektivitas dari kegiatan penyuluhan dan pendampingan dalam penangan dan pencegahan covid 19 sebagai upaya untuk mengatasi persoalan yang dihadapi masyarakat terhadap perkembangan psikologi masyarakat yang kecenderungan kearah distrub, munculnya banyak kematian, sesak napas, jantung bergetar, yang mengarah cepat mati kalau tidak ditangani dengan serius sudah efektif dilaksanakan. Hal ini terukur dari 75\% masyarakat yang telah mengikuti kegiatan tersebut mentaati prosedur tetap covid 19 sebagai upaya dalam pencegahan penyebaran virus corona dan masih ada $25 \%$ masyarakat masih bingung dan belum memahami benar virus corona dan menganggap bahwa virus ini hanya permainan politik saja.

b. Hasil dari kegiatan persiapan prakondisi sosial, sudah efektif dilakukan dalam memberikan penguatan dalam penanganan dan pencegahan penyebaran covid 19, melalui kunjungan kerumah-rumah dalam rangka pemecahan masalah- masalah yang dihadapi oleh masyarakat, sehingga rasa takut dan trauma yang timbul bisa dicegah lebih awal, karena untuk menghindari kepanikan warga masyarakat terhadap virus corona ini. Dalam rangka penguatan kegiatan ini, Tim Pengabdian Kepada masyarakat juga telah melakukan koordinasi dengan Lurah Rabangodu Selatan dan Dinas Kesehatan Kota Bima dan Satgas Penanganan dan pencegahan covid 19 Kota Bima.

\section{Tahapan Pelaksanaan}

Tahapan pelaksanaan kegiatan Program Pengabdian Kepada Masyarakat melalui penyuluhan dan pendampingan dalam penanganan dan pencegahan penyebaran Cvid 19 di 
Kelurahan Rabangodu Selatan kecamatan Raba Kota Bima, dapat jelaskan melalui skema sebagai berikut :

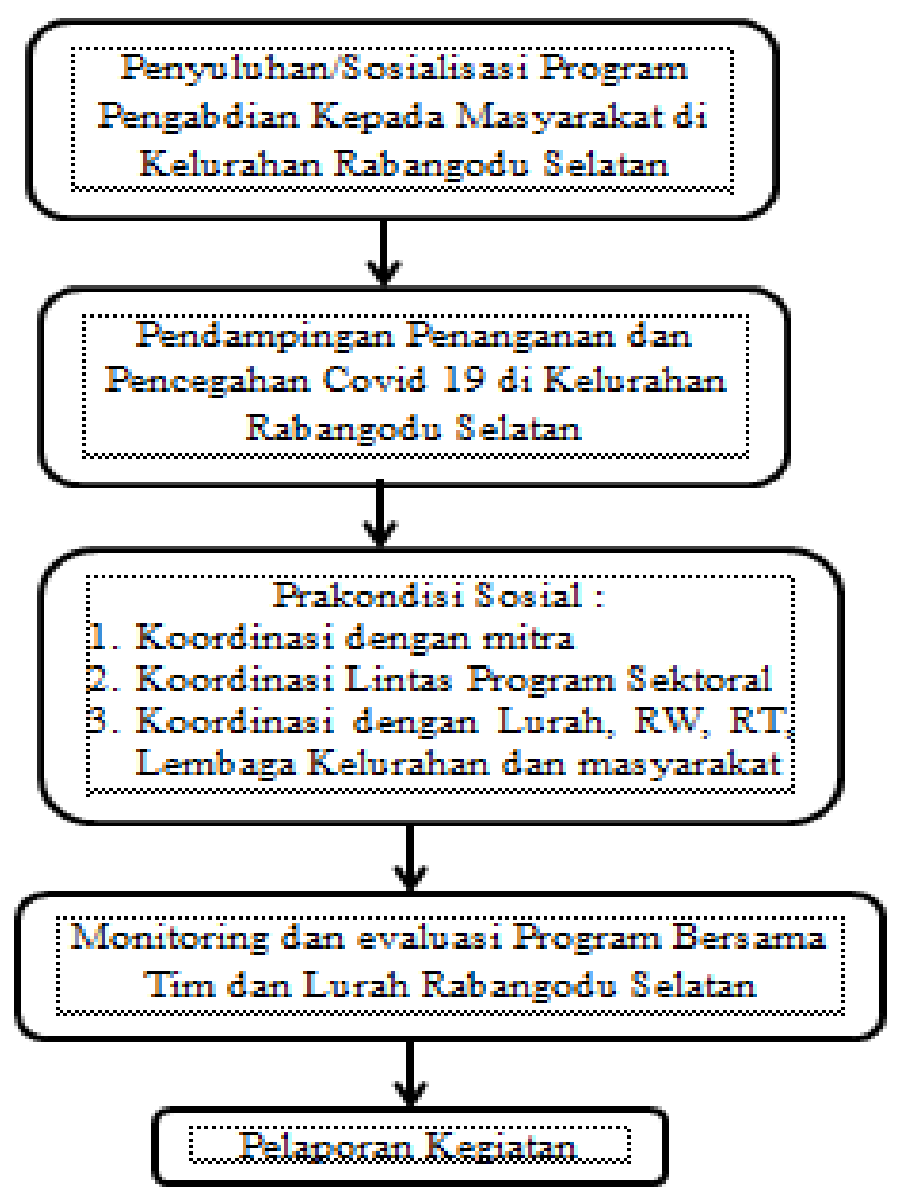

Skema 1 : Tahapan pelaksanaan kegiatan Program Pengabdian Kepada Masyarakat

Penanganan dan Pencegahan covid 19 dilaksanakan tahapan sebagai berikut : 1) Sosialisasi/Penyuluhan Pelaksanaan Penanganan dan Pencegahan covid 19.

Sosialisasi Program Pengabdian oleh Tim Pengabdian dimaksudkan untuk memperkenalkan program ini kepada Lurah dan Masyarakat Kelurahan Rabangodu Selatan. Pemberian sosialisasi tentang tujuan dan manfaat pelaksanaan Penanganan dan Pencegahan covid 19 sebagai representasi dalam rangka merubah prilaku hidup masyarakat menjadi bersih dan sehat.

Tujuan dari pelaksanaan kegiatan untuk menciptakan karakter masyarakat dalam memasuki era baru atau era new normal, dimana masyarakat sudah dalam keadaan memiliki kesadaran yang tinggi untuk tetap berprilaku, sebagai representasi masyarakat sehat.

Peserta Sosialisasi Program Pengabdian kepada Masyarakat terhadap Penanganan dan Pencegahan covid 19 dalam rangka untuk meningkatkan kualitas moral dan memiliki karakter yang dapat diimplementasikan di setiap lingkungan masyarakat, demi menjaga lingkungan masyarakat yang harmonis, nyaman dan berkarakter. Adapun materi sosialisasi adalah terdiri dari tujuan program Pengabdian kepada Masyarakat dari STISIP Mbojo Bima, faktor penyebab virus corona (covid 19), serta upaya pencegahannya, serta memberikan kesadaran bagi masyarakat untuk memecahkan persoalan yang dihadapi masyarakat terkait dengan penyebaran covid 19 di Kelurahan Rabangodu Selatan.

Kegiatan penyuluhan atau sosialisasi dilaksanakan di Aula Kantor Lurah Rabangodu Selatan Kecamatan Raba Kota Bima. Penyuluhan dan pendampingan ini dimaksudkan untuk memberikan wawasan ilmu terhadap dampak dari adanya penyebaran cpvid 19 yang sangat 
berbahaya dan mematikan. Sehingga masyarakat perlu diberi pencerahan untuk mempersiapkan diri sejak dini dalam mencegah dan menghindarinya, yang dibawa tim Pengabdian STISIP Mbojo Bima dengan Narasumber dari Dinas Kesehatan Kota Bima dan Satuan Petugas Penanganan Covid 19 Kota Bima.

Kegiatan penyuluhan atau Sosialisasi Program Pengabdian kepada Masyarakat dan penanganan dan pencegahan covid 19 terhadap Lurah, Babinsa, Babinkamtibmas, RW, RT, Ketua LPM, ketua Karang Taruna dan masyarakat dilaksanakan pada tanggal 15 Mei 2020, dengan jumlah peserta 50 orang, 4 orang Tim Pengabdian Kepada Masyarakat dan 1 orang Instruktur dari Dinas Kesehatan Kota Bima dan Tim Satgas Penangan Covid 19 Kota Bima.

Hasil yang dicapai dari adanya kegiatan sosialisasi perubahan prilaku masyarakat, adalah :

1. Jumlah peserta dari kalangan Lurah, RT, RW, Tokoh masyarakat dan perwakilan masyarakat sebanyak 50 orang hadir semua.

2. Narasumber telah memberikan sosialisasi berhubungan dengan kebijakan penanganan dan pencegahan covid 19 di Kota Bima.

3. Semua materi yang disampaikan oleh para Narasumber dapat diserap dengan baik oleh peserta penyuluhan/sosialisasi.

4. Dukungan Lurah dan masyarakat terhadap program Pengabdian kepada Masyarakat terukur dari menyediakan kursi kegiatan dan menyimak kegiatan sosialisasi di areal di luar tempat pelaksanaan sosialisasi.

5. Tim Pengabdian Masyarakat dari STISIP Mbojo Bima dapat melaksanakan koordinasi dengan baik dengan para pihak yang terkait dengan Program Pengabdian berdasarkan rencana telah ditetapkan sebelumnya.

Pada gambar 3 menjelaskan bahwa Tim Pengabdian kepada masyarakat melakukan kegiatan sosialisasi/penyuluhan tentang penanganan dan pencegahan Covid 19 bertempat di Aula Kantor Kelurahan Rabangodu Selatan. Kegiatan ini dihadiri oleh berbagai unsur baik dari Perangkat Kelurahan Rabangodu Selatan, Babinsa, Babinkamtibmas, RT, RW, Tokoh Masyarakat dan beberapa perwakilan masyarakat serta Satuan Tugas (Satgas) Covid 19 Kelurahan Rabangodu Selatan dan dari Unsur Dinas kesehatan Kota Bima. Kegiatan sosialisasi ini di buka oleh ketua Tim Pengabdian. Dan kata sambutan dari Bapak Lurah Rabangodu Selatan, dan dilanjutkan sosialisasi program oleh Ketua Tim Pengabdian dan Narasumber lainnya dari unsur Dinas Kesehatan Kota Bima yang diwakili oleh Satgas Covid 19 Kota Bima. Rangkaian kegiatan sosialisasi/penyuluhan dalam penanganan dan pencegahan covid 19, sebagai berikut:
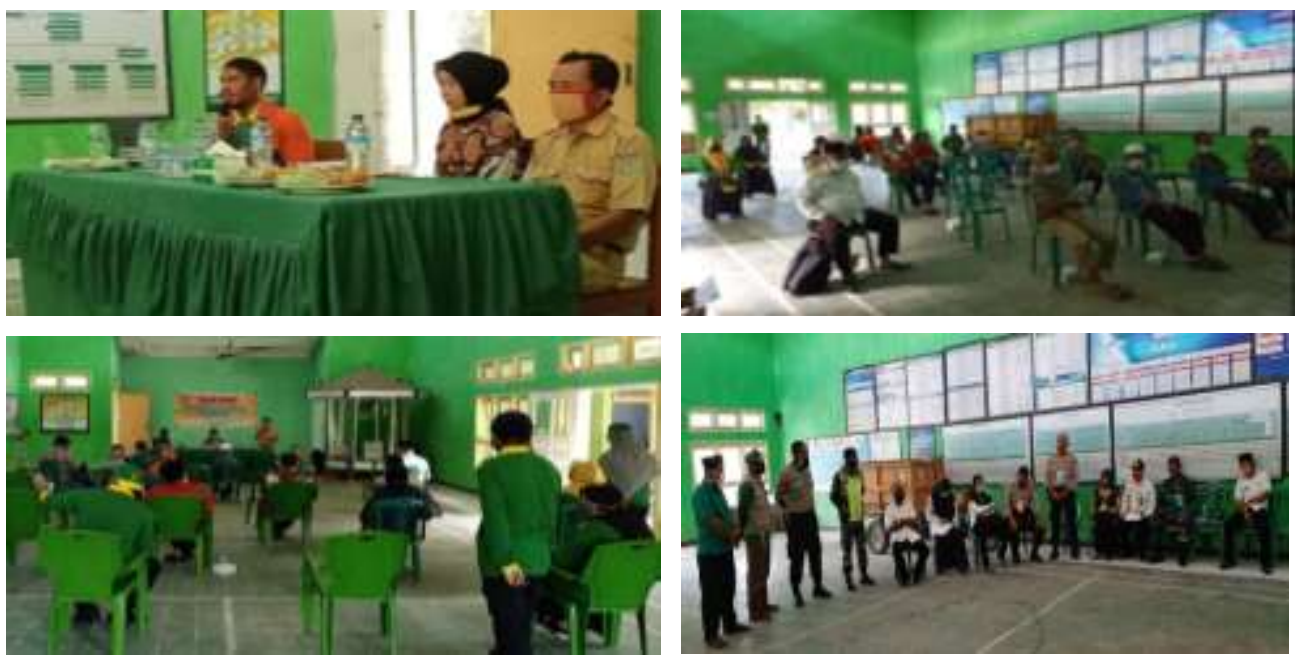

Gambar 3. Kegiatan sosialisasi/penyuluhan Penanganan dan Pencegahan Covid 19

2) Tahapan prakondisi sosial.

Melalui tahapan prakondisi sosial ini dimaksudkan untuk menyiapkan berbagai hal melalui kegiatan penanganan dan pencegahan covid 19, baik kepada Lurah dan masyarakat 
meliputi : (1).Koordinasi dengan mitra : Lurah Rabangodu Selatan dan masyarakat. (2). Koordinasi dengan lintas program dan lintas sektoral Pemerintah Daerah (Dinas Kesehatan Kota Bima dan Satgas Covid 19 Kota Bima).dan (3). Menguatkan kelembagaan Kelurahan RabangoSelatan dan Lembaga-lembaga kelurahan serta masyarakat.

Kegiatan Prakondisi Sosial sebagai wujud bentuk tanggungjawab semua pihak yang terkait dalam mendukung kegiatan Program Pengabdian di Rabangodu Selatan. Tim Pengabdian Masyarakat STISIP Mbojo Bima melakukan pendekatan kepada semua unsur terkait seperti Kepala Dinas Kesehatan Kota Bima Kota Bima, Lurah Rabangodu Selatan dan Tokoh-Tokoh masyarakat serta lain-lainnya. Bentuk kegiatan prakondisi sosial ini dilakukan mulai sebelum kegiatan Program Pengabdian Kepada Masyarakat dilakukan, pada saat pelaksanaan maupun telah berakhirnya kegiatan sebagai wujud tindak lanjut kegiatan ini, sehingga tujuan akhir kegiatan ini dapat membentuk masyarakat yang sudah dibinamelalui kegiatan penyusuluhan atau sosialisasi dan pendampingan dalam penanganan dan pencegahan covid 19 akan menjadi masyarakat yang taat dan patuh terhadap ketentuan maupun tata tertib atau prosedur tetap (protap) covid 19. Untuk itu dengan kesadaran yang tinggi untuk menjadi masyarakat yang sadar dan memiliki komitmen untuk tetap lingkungan masarakat sebagai lingkungan yang sehat, terutama dalam mencegah terjadinya covid 19 di Kelurahan Rabangodu Selatan.

Gambar 4 menjelaskan tentang kegiatan prakondisi sosial dimana Tim Pengabdian berkunjung ke rumah salah seorang Tokoh Masyarakat dan salah seorang Tokoh Agama Ustaz Islahuddin, S.Pdi untuk menyampaikan pelaksanaan program Pengabdian kepada masyarakat sekaligus sosialisasi penanganan dan pencegahan covid 19 di Kelurahan Rabangodu Selatan, supaya masyarakat selalu menerapkan prosedur tetap covid 19. Berikut disajikan kegiatan prakondisi sosial :
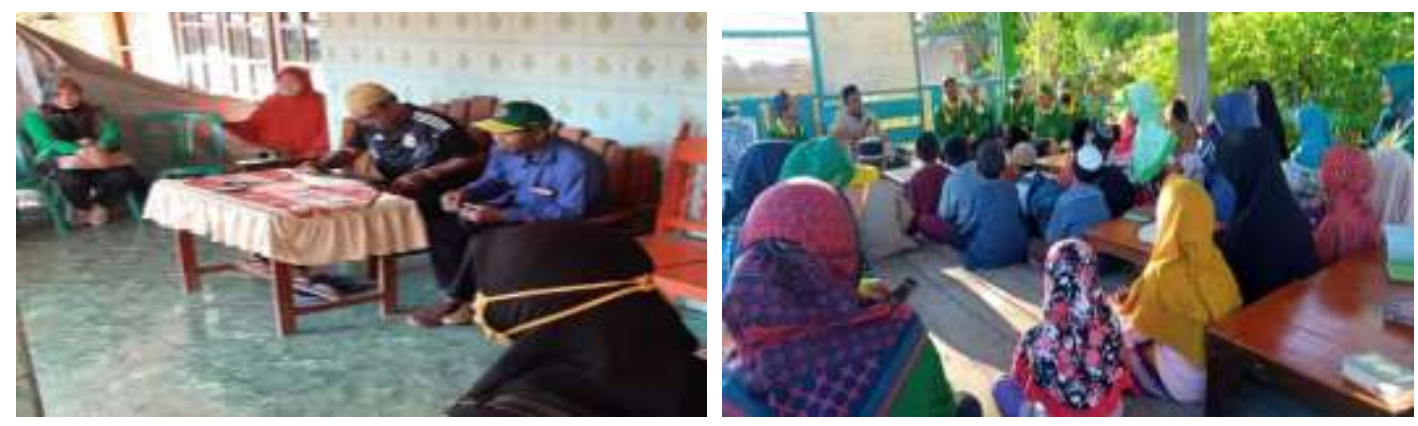

Gambar 4 : Tim Pengabdian Kepada Masyarakat bersama Tokoh Masyarakat, Babinsa, dan masyarakat Koordinasi Kegiatan Pengabdian Kepada Masyarakat melalui penanganan dan pencegahan covid 19 dengan mewujudkan Kampung Sehat bersih dan Indah

Dalam mempercepat penanganan dan pecegahan penyebaran virus corona (covid 19), maka Tim Pengabdian kepada masyarakat melakukan kegiatan pembagian masker dan pembagian hand sanitizer kepada masyarakat supaya masyarakat dapat menggunakan masker setiap saat bila berada diluar rumah dan selalu membawa hand sanitizer untuk digunakan dalam kondisi apapun. Seperti terlihat pada gambar 5. Selain pembagian masker dan hand sanitizer juga dilakukan penyemprotan lingkungan dilakukan oleh Tim Pengabdian bersama masyarakat, supaya lingkungan tetap steril dari bahaya virus sekaligus menciptakan lingkungan yang nyaman dan sehat. Serta menyiapkan isi ulang hand sanitizer bagi masyarakat yang memang sudah habis hand sanitizernya, kegiatan ini berlangsung selama kegiatan pengabdian kepada masyarakat di Kelurahan Rabangodu Selatan. Untuk lebih jelasnya terlihat pada gambar berikut ini : 

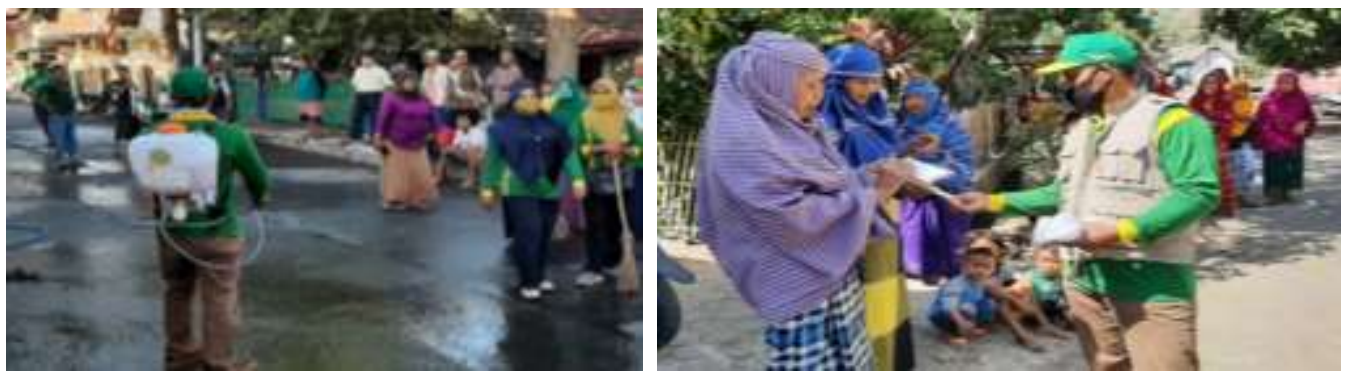

Gambar 5 : Tim Pengabdian Kepada Masyarakat melakukan kegiatan pencegahan Covid 19 dengan cara penyemprotan handsanitizer dan pembagian masker kepada masyarakat

\section{3) Tahapan Pendampingan}

Kegiatan penyuluhan atau sosialisasi dilakukan sebagai wujud dari tanggungjawab dalam memberikan pemahaman dan pengetahuan bagi Lurah dan masyarakat dalam mengimplementasikan penanganan dan pencegahan covid 19 kepada masyarakat dalam kehidupan sehari-hari-baik baik dalam lingkungan keluarga dan masyarakat agar mampu menciptakan lingkungan yang besuh dan sehat.

Pendampingan ini dilaksanakan 3 kali pertemuan di Lingkungan Masyarakat, dengan mendatangi masyarakat sambil melakukan sosialisasi dalam mewujudkan lingkungan bersih dan sehat. Pendampingan terhadap kegiatan kebiasaan masyarakat cuci tangan keluar maupun datang kerumah, menggunakan masker serta menciptakan lingkungan yang sehat dengan menanam tanaman apotik hidup disekitar lingkungan masing sebagai wujud dalam membentuk lingkungan yang bersih dan indah. Berikut disajikan gambar mengenai kegiatan pendampingan yang dilakukan oleh Tim Pengabdian Kepada Masyarakat di Kelurahan Rabangodu Selatan, sebagai berikut :
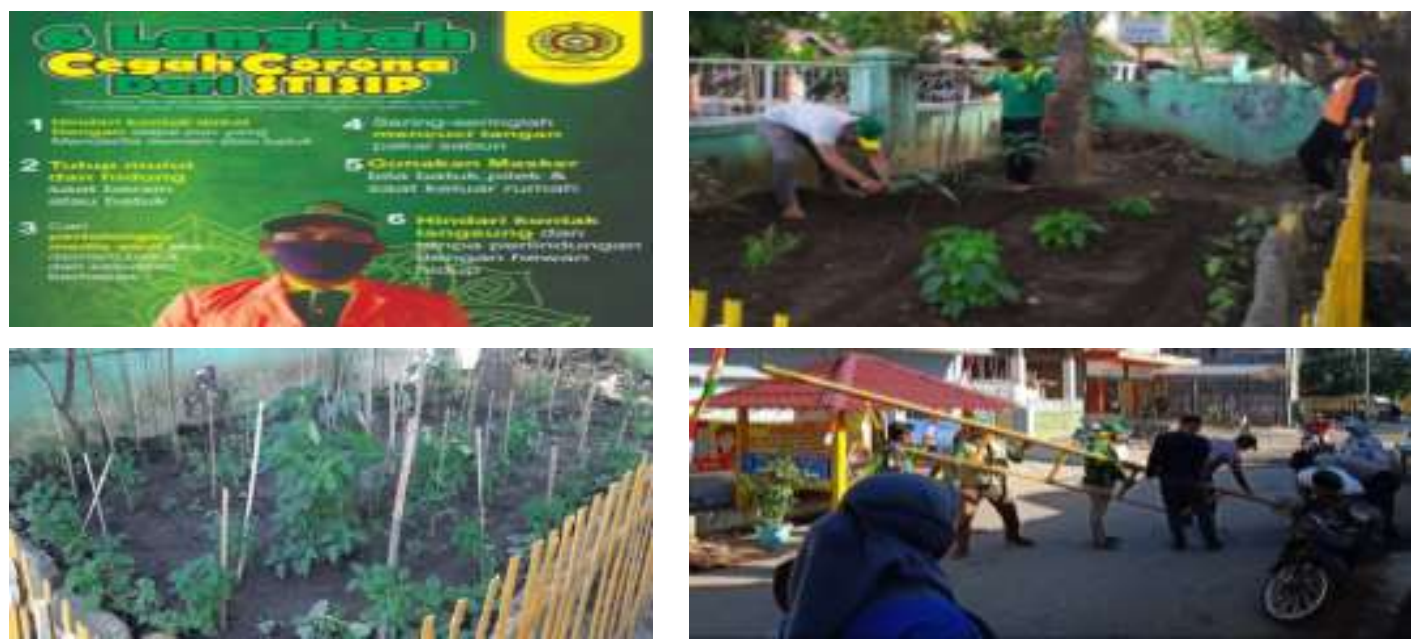

Gambar 6 : Tim Pengabdian bersama masyarakat dan Babinsa melakukan kegiatan penanaman apotik hidup dan membangun portal covid 19 di Kelurahan Rabangodu Selatan.

4) Monitoring dan Evaluasi

Tahap monitoring dilakukan agar proses keberlanjutan oleh Lurah dan masyarakat Kelurahan Rabangodu Selatan Kecamatan Raba Kota Bima, tentunya masih membutuhkan pembimbingan dalam proses pelaksanaan program. Hasil yang didapat dari kegiatan monitoring, yaitu :

1) Masyarakat memiliki kesadaran dalam menerapkan $3 \mathrm{M}$ (menggunakan hand sanitizer setiap saat, menggunakan masker dan menghindari kerumunan), dalam progress peningkatan masyarakat dalam upaya pencegahan dan pemberantasan virus corona (covid 19).

2) Satuan Petugas (Satgas) Gugus covid 19 Kelurahan Rabangodu Selatan bersama Lurah selalu melakukan monitoring keliling kelurahan untuk memantau masyarakat untuk 
tetap taat terhadap prosedur tetap covid 19 terutama pada kegiatan kemasyarakatan seperti hajatan pernikahan, kegiatan keolahragaan, dan kegiatan masyarakat lain untuk tetap menghindari kerumunan dan tetap menggunakan masker, sebagai manifestasi dalam pencegahan penyebaran covid 19.. kalau ada masyarakat yang masih melanggar akan di tegur secara langsung bahkan dikenakan sanksi untuk dikenakan denda supaya ada efek jera bagi masyarakat yang melanggar dimaksud.

3) Wujud konkrit dari hasil kegiatan pengabdian bagi masyarakat di setiap rumah sudah terlihat pemasangan tempat cuci tangan yang dilakukan kesadaran sendiri dari warga masyarakat, karena mereka menganggap dengan pola kebersihan yang diawali dari rumah akan tercipta lingkungan yang bersih dan sehat, hal ini sebagai representasi dalam merubah prilaku hidup masyarakat untuk tetap bersih dan sehat.

4) Disetiap Jalan lingkungan sudah dipasang Portal sekaligus dipasang baliho tentang sosialisasi pencegahan dan penyebaran covid 19 dan pemasangan pos jaga, dan setiap jam 10 malam sudah dilakukan ronda malam, untuk menghindari orang luar yang masuk ke lingkungan untuk membatasi kontak dini sebagai bagian dalam menghindari menjangkitnya penyebaran virus corona 19 di Kelurahan Rabangodu Selatan.

Tahap Evaluasi dilakukan untuk mengetahui kekurangan dalam pelaksanaan Program Pengabdian Kepada Masyarakat di Kelurahan Rabangodu Selatan Kecamatan Raba Kota Bima. Berdasarkan evaluasi yang telah dilakukan dapat terlihat kekurangan dan kelemahan yang ada dalam pelaksanaan pengabdian kepada masyarakat, sehingga kedepannya kegiatan ini lebih berkualitas dan bermutu, baik dari sisi pelaksana yaitu Dosen dan Mahasiswa, lebih-lebih pihak mitra dalam hal ini Lurah Rabangodu Selatan.

5) Pelaporan

Pelaporan kegiatan program pengabdian kepada masyarakat sebagai bentuk tanggungjawab dalam menyampaikan informasi yang berhubungan dengan tahapan kegiatan mulai dari sosialisasi atau penyuluhan telah dilakukan dengan memberikan hasil capaian dari adanya peningkatan kesadaran bagi warga masyarakat tetap patuh dan taat terhadap prosedur tetap covid 19 melalui pola $3 \mathrm{M}$ (mencuci tangan, memakai masker dan menjaga jarak), prakondisi sosial dengan berkunjung kerumah Tokoh Masyarakat maupun Tokoh Agama serta melakukan pendampingan sosial terhadap pelaksanaan program pengabdian terutama dalam kegiatan yang berhubungan pencegahan dan penyebaran virus corona di Kelurahan Rabangodu Selatan. Tahapan laporan kegiatan ini berupa :

a. Pembuatan LaporanKemajuan

Pembuatan laporan kemajuan disesuaikan dengan hasil yang telah dicapai selama melakukan pembinaan dan pendampingan terhadap penanganan dan pencegahan penyebaran Covid 19 di Kelurahan Rabangodu Selatan Kecamatan Raba Kota Bima. Memaparkan proses pelaksanaan program dari awal hingga perkembangan dari setiap program yang telah dilaksanakan.

b. Pembuatan LaporanAkhir

Laporan akhir dilakukan setelah semua program Pengabdian Kepada Masyarakat dilaksanakan, sesuai dengan tahapan dalam pelaksanaan program ini terhadap Lurah dan masyarakat di Kelurahan Rabangodu Selatan Kecamatan Raba Kota Bima

\section{KESIMPULAN}

Kontribusi Program Pengabdian Kepada Masyarakat untuk memberikan sosialisasi kepada warga masyarakat mengenai penanganan dan pencegahan penyebaran covid 19 di Kelurahan Rabangodu Selatan melalui perubahan perilaku hidup bersih dan sehat, sebagai wujud dalam menciptakan lingkungan yang bersih dan sehat, sebagai representatif dari pencegahan covid 19. Program pengabdian masyarakat ini merupakan salah satu upaya untuk membina dan membentuk masyarakat yang bermartabat, karena didalamnya dimana 
masyarakat sudah dapat memahami dan mengetahui manfaat dan tujuan dari pelaksanaan kegiatan pengabdian masyarakat yang dilaksanakan oleh dosen dan mahasiswa dalam membantu masyarakat untuk mencegah terjangkitnya covid 19 yang dapat membahayakan kelangsungan hidup bagi warga masyarakat di Kelurahan Rabangodu Selatan. Perlu pendampingan berkelanjutan dari kampus STISIP Mbojo Bima dan stake holder lainnya, setelah kegiatan pengabdian kepada masyarakat berlangsung. Sejauh ini pelaksanaan kegiatan pengabdian ini dirasa baik dan tepat sasaran, disamping itu juga menghasilkan luaran program dan luaran kegiatan sesuai dengan rancangan awal

\section{UCAPAN TERIMA KASIH}

Penulis menyampaikan ucapan terima kasih banyak kepada Lurah dan masyarakat Kelurahan Rabangodu Selatan Kecamatan Raba Kota Bima yang telah bersedia menerima Tim Pengabdian kepada masyarakat STISIP Mbojo Bima dalam pelaksanaan program pengabdian kepada masyarakat di Kelurahan Rabangodu Selatan.

\section{DAFTAR PUSTAKA}

Ali, Ramli. 2008. Prilaku Hidup Bersih dan Sehat . Jakarta: Departemen Kesehatan Republik Indonesia.

BPS. (2020). Kota Bima Dalam Angka. Kota Bima: BPS.

Fadjarudin, M. 2020, Maret 24). Hasil Kajian INDEF Soal Penanganan Wabah COVID-19 dan Dampak Ekonominya. . Dipetik Maret 20, 2020, dari Suara Surabaya tanggal 24 Maret 2020: https://www.suarasurabaya.net/ekonomibisnis/ 2020/hasil-kajian-indef-soal-penangananwabah-covid-19.

Gaffa, L. O. 1999. Pengantar Keperawatan Profesional. Jakarta: Penerbit Buku Kedokteran.

Hamid, A. H. (2005). Pengembangan Masyarakat Nelayan dan Kemaritiman (Suatu Studi SosioAntropologi Ekonomi). Makassar: PPS UNM.

https://indonesia.go.id/ragam/komoditas/ekonomi/mengenal-konsep-new-normal)

https://www.alodokter.com/virus-corona)

https://tirto.id/yuk-kolaborasi-lawan-covid-19-untuk-atasi-dampak-ekonomi-eHzg

Irwanto, B. 2003. Ilmu Kesehatan Masyarakat. Jakarta: Rineka Cipta.

Keputusan Menteri Kesehatan RI. No. 1193/MENKES /SK/X/2004 tentang Perilaku Hidup Bersih dan Sehat 2020" (PHBS 2020). Jakarta: Kemeterian Kesehatan.

Murni Br Karo, 2020; Perilaku Hidup Bersih dan Sehat (PHBS) Strategi Pencegahan dan Penyebaran Virus Covid 19, Proseding Seminar Nasional, Vol 1

Notoatmodjo, S. (2003). Pendidikan dan Perilaku Kesehatan. Jakarta: Rineka Cipta.

Razi dkk, 2020; Bunga Rampai Covid 19 : Buku Kesehatan Mandiri Untuk Sahabat, PD Prokami; Depok

Sadyohutomo, M. 2008. Kesehatan Lingkungan. Jakarta: Departemen Kesehatan RI .

Syaifudin.2020. Wabah Virus Corona dan Dampak Sosiologis. Jakarta: Tempo.co tanggal 3 Maret 2020. Diakses dari https://kolom.tempo.co/read/ 1314927/wabah-virus-corona-danmasalah-sosiologis. 